\title{
O CLARÃO QUE ILUMINOU A CIDADE: AS CONCESSÕES BOLONHA E A DERROCADA DA "ERA LEMOS" - MODERNIZAÇÃO E DISPUTAS POLITICAS NA CIDADE DE BELÉM DO PARÁ ${ }^{1}$
}

Adriana Modesto Coimbra²

\section{RESUMO}

A cidade de Belém no Pará passou por ampla reforma urbana no período de 18901911. Dentre os sujeitos que participaram deste processo de modernização da cidade, estão o Intendente Antônio Lemos e o engenheiro Francisco Bolonha. Neste artigo apresento uma visão geral sobre esta modernização e analiso como as concessões feitas por Lemos ao engenheiro Bolonha, além de contribuir para a modernização da cidade, provocou tensões no seio da politica local, contribuindo para que ocorresse o fim da chamada "era lemos". Pretendo, também, compreender sob que matrizes teóricas a urbanização da cidade de Belém se assentou e como os ideários do progresso, presentes no recém-proclamado Regime Republicano, foram recebidos e aplicados nesta urbanização. Para esta análise foram utilizados sete volumes dos Relatórios de Intendência Municipal, publicados entre 1897 e 1908 e diversos artigos publicados nos jornais locais, O Estado do Pará, A Província do Pará, Folha do Norte e O Jornal.

\section{Palavras-chave}

Modernização, Disputas Políticas, República

\section{ABSTRACT}

The city of Belém, Pará passed by an extensive urban renovation during 1890-1991. Among the people that that joined that city modernization process, are the Manager Antônio Lemos and the engineer Francisco Bolonha. In this article I present a overall view about that modernization and analyze how the concessions made by Lemos to the engineer Bolonha, besides contributing to the city modernization, caused tensions on the local politics, contributing to the end of the called "Lemos Era". I want also, to comprehend about what theoretical matrices the urbanization of Belém was applied and how the ideals of progress, present in the newly proclaimed Republican Regime, were received and applied in this urbanization. For this analysis were used seven

\footnotetext{
${ }^{1}$ Este trabalho é decorrente da pesquisa que desenvolvi para a minha dissertação que tem como tema a Modernização da cidade de Belém do Pará durante a Primeira República.

${ }^{2}$ Mestra pelo Programa de Pós-graduação em História da Universidade Estadual de Campinas (UNICAMP), sob a orientação da professora Dra. Cristina Meneguello. Pesquisa financiada pelo Conselho Nacional de Desenvolvimento Cientifico e Tecnológico - CNPq.
} 
volumes of Municipal Stewardship Reports, published between $1897-1908$ and several articles published on the local newspaper, O Estado do Pará, A Província do Pará, Folha do Norte e O Jornal.

\section{Keywords}

Modernization, Political Disputes, Republic

É consenso na historiografia amazônica que a economia da borracha financiou e intensificou o processo de modernização das cidades nortistas no final do século XIX e inicio do XX, principalmente de Belém no Pará e de Manaus no Amazonas (SANTOS, 1980; WEINSTEIN, 1993; SARGES, 2002; CANCELA, 2011)3. A modernização urbanística da cidade de Belém ocorreu, em grande medida, movida pela inserção do estado do Pará como consumidor dos produtos gerados pela Segunda Revolução Industrial, a reboque das ideias positivistas adotadas por alguns segmentos da sociedade brasileira e fortalecidas pela República nascente no Brasil.

Era corrente a ideia, durante o século XIX, de que a industrialização transformou a cidade em um formigueiro humano, propicio a desenvolver pestes, insalubridade e miséria. A noção de que as cidades eram 'organismos doentes' e precisavam ser curados, era compartilhada por muitos teóricos e literatos que pensavam a cidade (BRESCIANI, 1995). Mas, mesmo o estado do Pará sendo pouco industrializado, tendo o seu desenvolvimento centrado na lógica extrativista e comercial da economia do látex, durante grande parte da primeira República, o crescimento populacional, advindo da migração local, nacional, e internacional para o estado, incentivou a criação de códigos de postura, leis municipais e estaduais, visando higienizar, modernizar e, principalmente, educar e controlar a população pobre - vista como empecilho para a aplicação dos preceitos urbanísticos modernos. Os Relatórios anuais da Intendência, publicados entre 1897 a 1908, estão repletos de observações sobre a importância de se disciplinar o povo dentro dos preceitos da higiene. No Relatório de 1897-1902, ao falar sobre a situação em que teria encontrado a cidade, Antônio Lemos - Intendente de Belém de 1897-1911- diz o seguinte:

Por causa de benevolência com que era tratado o arrematante da limpeza publica de então, as ruas todas, ainda mais as centrais, ofereciam repugnante

\footnotetext{
${ }^{3}$ A exploração da goma elástica ganhou impulso a partir de 1870, propiciando a intensa urbanização do estado do Pará. Conhecido como ouro branco, o preço do látex passava por constantes flutuações no mercado, gerando riquezas e constante instabilidade. Em 1910 esta economia entrou em declínio tendo sobrevida até 1920 .
}

URBANA, V.5, no 7, out.2013 - Dossiê: Urbanistas e Urbanismo: a escrita da história... - CIEC/UNICAMP 
aspecto, e não era isto o mais próprio para estimular o zelo de uma parte da população que não compreende bem o seu dever de colaborar com o poder publico para o asseio geral (Relatório de Intendência. Belém: A.A. Silva, 18971902).

Portanto, podemos considerar que o processo modernizador ocorrido em Belém nas décadas de 1890 a 1910 foi uma ação politica, uma intervenção do Estado e uma diretriz de poder (COELHO, 2002. p. 28). Embora, não possamos perder de vista que este foi, também, um momento histórico situado dentro de uma conjuntura financeira favorável. Junte-se a estes fatores a posição geográfica privilegiada em que a cidade se encontra, facilitadora do processo de escoamento da produção gomífera. Estando situada junto à foz do Rio Amazonas, às margens da Baia do Guajará, a 120 km do mar - figura 1 - a cidade tornou-se importante entreposto de navios que entravam e saiam da região, transportando pessoas e mercadorias. A borracha produzida no Amazonas e no Acre era exportada pelo porto de Belém (CANCELA, op.cit., p. 32).

O Regime Republicano deu a municipalidade maior autonomia econômica e política, esta autonomia suscitou controversas desde o inicio deste Regime no Pará. Em 1898 o governador Paes de Carvalho sugeriu em seu relatório anual que fosse criado um Tribunal de contas para fiscalizar a aplicação da verba publica pelos Intendentes. Este governador alegava que a criação deste Tribunal seria "a válvula de segurança contra uma autonomia, que é[ra] entendida por muitos municípios como meio de tirania e opressão ${ }^{4 \prime}$.

Contudo, na visão do intendente Antônio Lemos, a autonomia administrativa que a Republica deu a Intendência Municipal, alavancou a modernização da cidade, já que a Intendência adquiriu maior liberdade de ação econômica e politica. Nas palavras de Antônio Lemos:

Com a Proclamação da Republica, passaram os municípios a ser autônomos, quando até então tinham vivido subordinados ao governo da província, com orçamentos feitos pela Assembleia Provincial.

A Constituição ampliou consideravelmente a raia dos poderes municipais; o conselho [municipal] orça a receita e fixa a despesa do município; crea impostos aplicando o seu producto como convier as necessidades dos serviços; contrae empréstimos, recorre a outras operações de créditos; resolve sobre alienação, troca ou hypotheca de imóveis; adquire a titulo gratuito ou oneroso os imóveis necessários; desapropria para a utilidade municipal; regula as posturas; apura as eleições dos seus membros e do intendente; crea emprego e fomenta a instrução do município.

No período republicano e com especialidade nos últimos anos, a corporação municipal tem adquirido uma grande importância, no exercício das amplas atribuições que a constituição Ihe conferiu. O município de Belém possui uma

\footnotetext{
${ }^{4}$ Governador José Paes de Carvalho. Mensagem ao Congresso do Estado do Pará. Belém: Tipografia do Diário Oficial. 1898. P. 23-31.

URBANA, V.5, no 7, out.2013 - Dossiê: Urbanistas e Urbanismo: a escrita da história... - CIEC/UNICAMP
} 
longa série de grandes melhoramentos, realizados dentro deste curto período de doze anos (A municipalidade de Belém, Álbum de Belém do Pará, 1902).

Além dos impostos impingidos sobre a moradia e o consumo da população, a urbanização da cidade de Belém concretizou-se financiada pelos empréstimos contraídos pela Intendência. Antônio Lemos, por exemplo, emprestou no Brasil, cerca de 20 mil contos de reis e para saudar esta divida, contraiu outras duas dividas fora do país. Do Ethelburg Sindicate em Londres, emprestou 1 milhão e 60 mil libras esterlinas, sendo que a receita anual da Intendência não chegava a 7 mil contos de réis (Tabela $n^{\circ} 1$ ) - valor que corresponderia na época a 623 mil libras esterlinas entre outros empréstimos contraído durante o seu governo (SARGES, op.cit., p.142$143)^{5}$.

Tabela 1: Receita dos anos de 1897-1902

Fonte: Relatório de Intendência. 1897-1902. P. 321

\begin{tabular}{cc}
\hline Ano & Receita \\
\hline 1897 & $436: 506 \$ 080$ \\
1898 & $5.295: 852 \$ 894$ \\
1899 & $6.110: 096 \$ 819$ \\
1900 & $6.419: 028 \$ 434$ \\
1901 & $5.735: 394 \$ 524$ \\
1902 & $3.837: 826 \$ 742$ \\
\hline
\end{tabular}

Aliás, é importante que se diga que o investimento do capital local, foi uma das especificidades da urbanização no Pará. Barbara Weinstein (1993) assegura que, os comerciantes paraenses, à medida que progredia a expansão da borracha, diversificavam seus investimentos. Muitas obras públicas foram financiadas com capital local. Linhas de bonde, abastecimento de água, iluminação pública e rede telefônica, tudo isso foi, até certo ponto, custeado e gerido por paraenses ou moradores do Pará. Mesmo que muitos destes empreendimentos não tenham lograram sucesso, sendo substituídos por empresas estrangeiras. Ainda assim, em uma época em que os serviços públicos da América Latina estavam quase que exclusivamente, sob a propriedade e direção de empresas europeias ou norteamericanas - era muito significativo que as elites amazônicas, com capital local, investissem e tivessem os serviços públicos mais modernos (WEINSTEIN. op. cit. 1993, p. 109). No âmbito econômico, foi este o tripé que patrocinou a modernização de Belém do Pará: capital estatal, capital estrangeiro e capital privado local e nacional.

${ }^{5}$ Sobre a totalidade dos empréstimos, ver: Relatórios de Intendência. Belém: A.A. Silva, 1902 a 1908. URBANA, V.5, n० 7, out.2013 - Dossiê: Urbanistas e Urbanismo: a escrita da história... - CIEC/UNICAMP 
Gradativamente os signos de riqueza foram se diversificando na Belém da virada do século XX. Os antigos proprietários de terra, criadores de gado, funcionários públicos e militares, foram impelidos a adaptarem-se aos novos tempos. Os seringais, casas de aviação e comerciais, ações da bolsa de valores e imóveis urbanos, passaram a compor as fortunas da elite local ${ }^{6}$.

Com a acentuação do aburguesamento do gosto da elite paraense, o sucesso da economia da borracha e a modernização do espaço urbano e dos serviços, ampliou-se a oferta de produtos importados. Havia uma grande variedade de ofertas de mercadorias vindas da Europa em navios que aportavam em Belém, trazendo novidades de todos os tipos ${ }^{7}$. A casa comercial Paris $N^{\prime}$ América é um dos exemplos mais emblemáticos e conhecidos de estabelecimento destinado a atender aos gostos burgueses das famílias abastadas paraenses ${ }^{8}$.

Em matéria de comunicação, "a capital do Pará comunicava-se com o mundo pelas linhas submarinas da Western \& Brazilian Telegraph Company, e da Compagnie Française des Cables Telegraphiques" ${ }^{\prime \prime}$. Sua comunicação com o sul do País dava-se pelas linhas terrestres do Telegrapho Nacional, e com o interior do Estado e Manaus

${ }^{6}$ Os relatórios dos Presidentes de Província estão abarrotados de reclamações sobre a falta de produtos de primeira necessidade, provocada pela febre da borracha. Em 1860, por exemplo, o presidente da Província aponta o prejuízo que esta atividade econômica estaria trazendo a agricultura local, salientando que os moradores da província encantavam-se com os preços que a seringa vinha atingindo no comércio local e no exterior. Não exigindo a exploração deste produto, nada mais que um homem robusto, um machado e alguns vaso de barro para aparar o suco, rendendo uma média de 20 libras por dia, estava caindo na preferência da população, prejudicando o cultivo ou a extração do açúcar, do café, do urucum, do cravo, do cacau, da baunilha e de outros produtos. Ver: Relatório que o Antônio Coelho de Sá e Albuquerque, presidente da província do Pará. Typ. Commercial de A.J. Rabello Guimarães. 12 de maio de 1860. p. 41 . Relatório de Domingos José da Cunha Junior, presidente da província. Pará, Typ. do Diario do Gram-Pará, 1873. p. 38-39. Relatório do presidente da Província, dr. Abel Graça. Pará, Typ. do Diario do Gram-Pará, 1872. p. 58. Cristina Cancela analisando as motivações que levavam aos arranjos de casamento entre as famílias no Pará fez uma boa análise de como a economia gomífera inseriu novos símbolos de riqueza às fortunas locais. (CANCELA. op.cit. p. 23).

7 Na coluna Editais, do jornal local Folha do Norte, por exemplo, desde, pelo menos, meados do século XIX, anunciava-se a entrada de produtos importados, vindos da Europa e América do Norte. Estas mercadorias eram importadas pelos comerciantes locais, assim como, pelas famílias abastadas do Estado.

${ }^{8}$ A Paris N'América foi a primeira casa comercial a ser registrada na Junta Comercial do Pará - JUCEPA em 1877, embora o solar que lhe serve de sede, só tenha sido construído nos anos de 1906 a 1909. Em estilo Art Nouveau, o estabelecimento pertencia ao comerciante português, Francisco de Castro que importou de Paris este projeto de estabelecimento, misto de casa residencial e comercial. Este estabelecimento é um excelente exemplo da composição diversificada dos prédios locais surgidos durante a chamada Belle-époque amazônica, construídos com materiais e mão de obra importados de diversos países. Por causa da escassez de mão de obra especializada, fez-se necessário trazer um técnico competente da Europa para montar a escada em ferro fundido, importada da França - um dos destaques do estilo Art Nouveau em Belém. A construção deste prédio foi feita sob a coordenação do engenheiro, Raimundo Viana e seu mestre de obras Salvador e Mesquita. A estrutura do prédio é composta totalmente por aço, importada da Escócia, o piso de cerâmica e o relógio são Alemães, o telhado de barro plano, vindo da Ardósia, os azulejos e a pedras foram importados de Portugal e a louça da Inglaterra, o lustre e as lâmpadas foram importadas da França. Apenas as esquadrias de acapu e o piso da sobreloja e da residência, em acapu e pau amarelo, foram feitos com material regional. Célia Bassalo assegura ter recebido estes dados na década de 1980, do engenheiro Francisco de Castro Henriques, neto do primeiro proprietário deste monumento, que seria possuidor de documentos que comprobatórios destas informações. (BASSALO, 2008, P. 118-122).

${ }^{9}$ Revista A Semana, 1908. s/n.

URBANA, V.5, no 7, out.2013 - Dossiê: Urbanistas e Urbanismo: a escrita da história... - CIEC/UNICAMP 
pelas linhas sub-fluviais da Amazon Telegraph Company $L t d a^{10}$. "Foi em Belém a cidade onde primeiro se estabeleceu no Brasil o Telegrapho sem fio ${ }^{11 " . ~ E m ~ 1908, ~ e s t a ~}$ cidade já possuía rede telefônica com 500 assinantes, sem considerar os aparelhos das repartições públicas, que eram praticamente todas aparelhadas com telefone ${ }^{12}$. Evidentemente que estes serviços não atendiam a totalidade da população de uma cidade que, na época, excedia o número de 90 mil habitantes, mas importa percebermos nestas informações, a disposição que havia por parte da elite financeira e politica belenense em consumir ícones comerciais do mercado moderno.

O relatório da administração municipal, do período de 1897 a 1902, deixa claro sob que matrizes teóricas a urbanização da cidade foi desenvolvida. Dizia ele:

A abertura de novas avenidas, para fazer penetrar o ar e o sol em bairros e quarteirões insalubres; o calçamento em larga escala e conservação das vias públicas, para impedir a infecção do solo; a arborização das praças e avenidas, para entreter a pureza da atmosphera; a regulamentação da edificação urbana; a incineração das immundícies; o aterro e drenagem dos pântanos; a construção dum cemitério modelo; a remoção do matadoiro e estabelecimentos insalubres; a creação de novos arrabaldes; o desenvolvimento material e moral dos districtos do interior; e a construção de uma rede de esgoto destinada a recolher os resíduos da vida animal, para transportal-os ao longe e utiliza-lo em proveito da agricultura, a par com uma distribuição de agua sã e largamente abundante, para satisfazer a todos os usos domésticos e todas as necessidades do serviço público (O Município de Belém. Relatório Municipal. Belém: A. A. Silva. 1897-1902).

Neste mesmo relatório justifica-se, na voz do intendente, a feitura destes serviços: "tudo isto indica em suas grandes linhas as condições fundamentais do saneamento de Belém e revela que na administração do município um dos meus maiores cuidados se tem prendido a salubridade publica e a hygiene geral da cidade ${ }^{13 \prime}$. O relatório de Antônio Lemos denuncia um estreito contato de seus engenheiros com as pesquisas que levaram ao desenvolvimento da engenharia sanitária, disciplina que desde o seu aparecimento preocupava-se com a criação de instrumentos operativos, com o objetivo de impedir o surgimento e a propagação de doenças. Há nas intervenções sobre o espaço da cidade, desde o século XIX, uma relação de causa e efeito, resultado da cultura positivista e do determinismo oitocentista (CALABI, 2001, p.105).

\footnotetext{
10 Esta linha foi lançada em 1905, durante o governo de Lauro Sodré. Mensagem para o Congresso do Estado do Pará. Belém: Typ. Do Diário Oficial, 1896. P. 51.

${ }^{11}$ Revista A Semana, 1908. s/n.

${ }^{12}$ Revista A Semana, 1908. s/n.

13 Idem. p. 16.

URBANA, V.5, n 7, out.2013 - Dossiê: Urbanistas e Urbanismo: a escrita da história... - CIEC/UNICAMP
} 
Assim como para outras cidades brasileiras, a cidade de Paris serviu de inspiração para a urbanização de Belém ${ }^{14}$. Esta inspiração foi enfatizada por diversas vezes pelos governantes locais. Destacavam-na, em 1908, em um número especial sobre o Pará da Revista da Semana:

O Pará, mais próximo da Europa do que Rio do Janeiro, com os seus interesses mais ligados ao velho continente e a América do Norte do que ao Brasil de que faz parte, não é para extranhar ser mal apreciado por quem nada ou quase nada sabe dos seus homens e dos seus negócios, pelo pouco interesse immediato despertado por tão longiqua região (Revista da Semana. 1908).

Tentava-se construir uma aproximação identitária com o 'velho mundo', a partir da necessidade de inserção econômica e política no "mundo moderno". A distância geografia da capital do país e a facilidade de chegar a Europa pelo oceano, em alguma medida, aproximava Belém da Europa, mas havia, também, certo ressentimento em relação a capital, talvez pelo fato de a região Norte contribuir significativamente com a receita do país e não receber o reconhecimento politico que os membros da elite local desejavam. Belém começou a remodelar-se fisicamente a partir de 1870, tendo este processo sido acelerado a partir de 1897. O contato com as teorias urbanísticas e sanitaristas que surgiam, os jogos políticos armados durante a primeira República e o aburguesamento do gosto da elite local, levou ao alargamento das ruas, a derrubada dos chamados pardieiros, a criação de serviços modernos. E a intensa importação de produtos diversos, compunha o cenário da Belém da virada do $X X$, que seus contemporâneos batizaram de Moderna. "A forma do espaço é social" (MENEZES, 2001, p. 14), mas é, também, definida pela forte influência do político.

Em 1897 a municipalidade abriu concorrência em Belém, na Capital Federal, nos Estados Unidos, na Inglaterra, na Alemanha, na França e na Bélgica para construção, alargamento e exploração de avenidas ${ }^{15}$. Em 1898 deu inicio ao processo de abertura e alargamento das avenidas da cidade. Foram executadas várias benfeitorias, como serviço de esgoto, terraplenagem, nivelamento, revestimento das ruas por paralelepípedo de granito ${ }^{16}$.

\footnotetext{
${ }^{14}$ No relatório de 1897-1902, Antônio Lemos assegura que: "O sr. João Batista de Brito Pereira, quando em Paris, não se descuidou de estudar o melhor systema de dragas, para poder indicar-me, segundo incumbência, um bom serviço de limpeza das docas do Ver-o-Peso, Reduto e Souza Franco. (...) Neste estudo o sr. Brito Pereira foi sempre acompanhado por pessoa competente no ramo da engenharia hydraulica" - provavelmente A. Lemos referia-se ao engenheiro Francisco Bolonha, um dos seus maiores concessionários na construção de obras públicas, possivelmente o único especialista em Hidráulica que havia em Belém. Relatório de Intendência - 1897-1902. P. 357.

${ }^{15}$ O Município de Belém. Relatório de Intendência Municipal. Belém: 1897-1902. P. 169.

${ }^{16}$ Idem. p. 168.

URBANA, V.5, no 7, out.2013 - Dossiê: Urbanistas e Urbanismo: a escrita da história... - CIEC/UNICAMP
} 
O código de policia municipal republicano, instituído em 1900, substituiu o anterior, sendo reformulado por diversas vezes, conforme o surgimento das necessidades modernizadoras dos administradores da cidade $^{17}$. Numa das reformulações deste código, a intendência Municipal, por meio da lei n. 320 de 1902, impôs a obrigatoriedade da platibanda e do alinhamento dos prédios da cidade. Em nome dos ideários da modernidade, normatizou-se o espaço urbano a ponto de definir-se, quase com naturalidade, a ocupação territorial pelo poder monetário. Como era comum nos processos de modernização das cidades neste período, à medida que a população não conseguia atender as exigências das mudanças tipológicas nas construções arquitetônicas, foi sendo empurradas para as áreas suburbanas de então. $O$ código de posturas da cidade impunha regras cada vez mais severas à população. A câmara municipal aprovou em dezembro de 1898 a lei numero 218, autorizando o Intendente a reorganizar o serviço sanitário Municipal. Esta mesma lei, Instituiu as visitas domiciliares e nos estabelecimentos comerciais, para averiguar as condições de higiene dos prédios da cidade. Os municípios foram divididos em distritos sanitários e os médicos encarregados da vacinação e revacinação voluntária da população ${ }^{18}$.

Jussara Derenji (1998, p. 110) considera que, dois princípios nortearam o Código de Polícia - a higiene e a estética. Acrescento a eles as necessidades de controlar a circulação da parcela indesejada da população - as ditas "classes perigosas" - e de impor a esta classe um padrão comportamental. Pois, é importante atentarmos para a observação de Sidney Chalhoub sobre que, insistir em conceitos como "limpeza" e "beleza" e os seus correlatos, para entender a ação saneadora dos "teóricos" e "práticos" da cidade no final do século XIX e inicio do XX, não nos permite enxergar para além da aparência dos discursos, pois, para ele, por trás da declaração literal da intenção de "fazer a civilização europeia nos trópicos", está à intenção de "se fazer politica, deslegitimando o lugar da politica na história" (CALHOUB, 1996, P. 35). Ao contrário da crença vigente, de que os pobres não tinham lugar na nova cidade republicana, acredito que eles eram os que tinham o seu lugar melhor definido. Desse modo, à população de baixa renda, os "donos da cidade" reservaram as zonas periféricas, criando instituições para abriga-la, controlando o seu acesso real as áreas aonde tudo o que fugia das normas impostas deveria ser enquadrado a elas ${ }^{19}$. $\mathrm{Na}$

17 BELÉM. Lei n. 276, de 03 de julho de 1900. Institui o Código de Polícia Municipal. Lex: Leis e Resoluções Municipaes e Actos do Executivo, Belém, 1900.

${ }^{18}$ O Município de Belém. Relatório de Intendência Municipal. 1897-1902. P. 16 e 19.

${ }_{19}^{19}$ Refiro-me aqui a criação de instituições como o Asilo de Mendicidade, inaugurado em 1892, Orfelinato Paraense, criado em 1893, transferido em 1901 para a municipalidade e reinaugurado em 1908, com o nome de Orfelinato Antônio Lemos e o Lyceu Paraense de artes e ofícios Benjamin Constant fundado no final do século XIX - todos construídos fora do raio urbano de Belém, objetivando educar ou retirar da sociedade pessoas que não cabiam no ambiente normatizado da cidade.

URBANA, V.5, no 7, out.2013 - Dossiê: Urbanistas e Urbanismo: a escrita da história... - CIEC/UNICAMP 
imagem que se queria produzir sobre a cidade de Belém, não cabia desvios das ideologias sociais e econômicas.

Neste novo cenário belenense, Antônio Lemos, em particular, ocupa na memória da cidade, o lugar do grande modernizador ${ }^{20}$. É impossível negar a sua importância neste processo, pois está claro que a História é feita por homens, ainda que o contrário não seja, de todo, uma afirmação falsa. Contudo, falta a historiografia paraense uma discussão mais profunda sobre as ideologias que nortearam o processo urbanizador do estado do Pará na virada do século $X X$, suas especificidades e generalizações, quais grupos participaram de forma ativa deste processo e como o fizeram. Os engenheiros, certamente, tiveram papel primordial - pois estes, junto com os médicos, encastelaram-se e acumularam poder na administração pública, após 1889 (CALHOUB, op.cit., P. 35).

Quando assumiu a intendência de Belém, Lemos encontrou uma conjuntura favorável ao projeto que vinha sendo implantado na cidade desde o Império, e ele continuou a desenvolvê-lo com sucesso. Lemos tinha a sua disposição engenheiros que mantinham estreita ligação com os conceitos urbanísticos do seu tempo e tendo os instrumentos necessários, assim como, os profissionais capacitados, colocou em prática um projeto modernizador que dizem, causou surpresa em muitos passantes pela cidade. É evidente que ele poderia ter seguido outras diretrizes em relação à modernização de Belém, mas quais matrizes modernizantes estavam a sua disposição no período? A cidade antiga, colonial, símbolo do atraso, não atendia mais as necessidade dos novos tempos, a 'Paris Haussmanniana', que "pretendia dar a ilusão de perfeita homogeneidade do espaço urbano" (HAROUEL, 1990. P. 113), foi a inspiração para muitas cidades latinas - Argentina, Rio de Janeiro, São Paulo, Buenos Aires - sendo, também, a inspiração para a então Belém do Grão Pará.

Das características politicas da urbanização de Belém neste período, a que mais chama a atenção, são as concessões a particulares que eram defendidas por Antônio Lemos, sob a justificativa de serem necessárias para os países novos, onde, em seu entendimento, "a anemia de capitais seria o único empecilho para o progresso"1". Por meio desta estratégia, ele criou o que Carlos Rocque (1973, p.20) definiu como "a maior oligarquia que já houve no Pará, enfrentando os maiores nomes do republicanismo local". Muitas destas concessões foram dadas a engenheiros. Elas certamente contribuíram para o desenvolvimento urbano da cidade, mas, também, propiciaram grandes vantagens financeiras e políticas a quem as conseguia e a quem

\footnotetext{
20 Natural do Maranhão. Foi intendente de Belém de 1897-1911.

${ }^{21}$ O Município de Belém. Relatório de Intendência Municipal. 1897-1902. p. 281.

URBANA, V.5, no 7, out.2013 - Dossiê: Urbanistas e Urbanismo: a escrita da história... - CIEC/UNICAMP
} 
as cedia. Algumas delas foram cedidas a Francisco Bolonha, duas delas foram o caminho da ruína para Antônio Lemos. Vamos entender como, a partir de agora.

Francisco Bolonha, além de um engenheiro muito conhecido na cidade de Belém, ficou famoso por ser um astuto negociante, dedicado a explorar concessões cedidas pela Intendência Municipal e a dirigir as empresas particulares de sua propriedade, das quais esteve à frente até o fim da sua vida ${ }^{22}$. Vivendo em uma cidade em franco desenvolvimento, que se expandia e se normatizava, Bolonha explorou o comércio local, oferecendo as últimas novidades em matéria de modernidade à "boa sociedade" belenense. Sua empresa Bolonha Paiva \& Cia, oferecia gelo no varejo e no atacado, produto muito útil para a conservação de alimentos, numa cidade onde a alta umidade e o calor excessivo deterioram os alimentos rapidamente ${ }^{23}$. O gelo era fornecido sob encomenda ou vendido na rua em carrinhos apropriados para este fim. Bolonha, também, oferecia serviços de escavação de poços artesianos, para fins domésticos e comerciais $^{24}$. As propagandas veiculadas nos jornais locais sobre a fábrica de gelo garantiam que seu produto era feito com água pura, fortificante e depurativa do sangue, uma referencia a um suposto poder curativo da água, elemento que ganhara status medicinal desde o século XVIII (CORBIN, 1989, p. 85).

O maquinário destas empresas, em sua grande maioria, era importado da América do Norte, país que figurava entre os lideres da industrialização no século XIX e inicio do XX. Com dupla função profissional, Bolonha ocupava, também, dupla função como agente da modernização, identificando na cidade o lócus privilegiado para a inserção de elementos desta modernidade. Os engenheiros, ambicionando atingir o modelo industrial do velho mundo, contrapunham-se a sociedade tradicional e agrária, formando, juntamente com os médicos e juristas, o tripé que acreditavam ser a sustentação que conduziria o país ao cosmopolitismo e consequentemente, ao desenvolvimento industrial e ao sucesso econômico (SEGAWA, 1999, p.18-19; CERASOLI, 1998).

As primeiras notícias que encontrei sobre Francisco Bolonha, após o término do seu curso de engenharia civil na Politécnica do Rio de Janeiro e seu retorno à Belém, datam do ano de 1895. Bolonha assinava, como secretário da comissão diretora dos festejos de 15 e 16, uma nota em um jornal local, convidando os integrantes desta

\footnotetext{
${ }^{22}$ Natural do Pará. Estudou engenharia da Politécnica do Rio de Janeiro. Construtor de várias obras que modificaram o fazer arquitetônico local, como: O palacete Bolonha, o palacete Bibi Costa, o prédio do jornal Folha do Norte - entre outras.

${ }^{23}$ A fábrica de gelo funcionava na Rua Bragança, n. 1 e mantinha escritório na Praça da Independência, n. 32. Empresa de Gelo Paraense. Folha do Norte. 15 mai. 1900.

${ }^{24}$ Folha do Norte. 25 març. 1901, p. 6.

URBANA, V.5, n 7, out.2013 - Dossiê: Urbanistas e Urbanismo: a escrita da história... - CIEC/UNICAMP
} 
comissão a reunirem-se para tratar da programação da festa ${ }^{25}$. Dias depois, há um anuncio de mesma natureza, comunicando o cancelamento de uma das atividades da festa ${ }^{26}$. Sendo esta uma comemoração oficial, está claro que Bolonha esteve sempre, de alguma forma, próximo ao poder no Estado. No mesmo ano, Bolonha veiculou nos jornais da cidade anúncios oferecendo seus serviços de engenheiro, onde declarava que poderia ser "encontrado diariamente na Intendência Municipal de 1 às $3 \mathrm{~h}$ da tarde $27 "$. Não tardou para que esta proximidade ao poder lhe rendesse contratos de construções com a Intendência Municipal.

Em 1898 ele assinou com a intendência o termo de concessão para assentar uma Montanha Russa, no largo do chafariz - à travessa piedade. O contrato estipulava que as instalações deste negócio deveriam ter como referência a América do Norte, devendo adotar os aperfeiçoamentos que este continente havia introduzido neste gênero. Além disso, ficava o concessionário obrigado a nivelar o local para facilitar o trânsito público, construir calhas de cimento para escoamento das águas pluviais e arborizar toda a praça ${ }^{28}$. Em 1900 houve ampla divulgação deste negócio nos jornais da cidade que o vendiam como "o mais atraente centro de diversões da América do Sul $^{29 \prime}$. Este foi o primeiro dos vários contratos firmados entre Francisco Bolonha e a Intendência de Antônio Lemos.

Em 1904 Francisco Bolonha firmou novo contrato com a Intendência para construir quiosques por toda a cidade ${ }^{30}$. Estes eram pequenos prédios em madeira e ferro, destinados a vender cafés, charutaria, botequins, papelarias, livrarias, drogarias, permutarias, joalherias, jornais e revistas, bilhetes de loteria e afins. O concessionário poderia explorar este negócio por vintes anos, findo este prazo, o negócio passaria as mãos da municipalidade. Firmou, também, contrato em 30 de novembro de 1906 para reforma e exploração do Mercado Municipal, atual mercado Bolonha, pelo prazo de 30 $\operatorname{anos}^{31}$.

\footnotetext{
${ }^{25}$ Trata-se dos festejos em comemoração a Proclamação da República. 15 e 16 de novembro. A Província do Pará. Seção Livre. 25 out. 1895. n/p.

${ }^{26} 15$ e 16 de novembro. Corrida de velocípedes. A Província do Pará. 12 nov. 1895. n/p.

${ }^{27}$ Engenheiros. Francisco Bolonha - engenheiro civil. A província do Pará. 1895.

${ }^{28}$ Intendência Municipal de Belém. Cópias de contratos. Pará: typ. Pinto Barbosa e Cia. 1900. P. 71 a 75.

${ }^{29}$ Ferro Via Aérea Sensacional. A Província do Pará. 11 mai. 1900.

${ }^{30} \mathrm{~A}$ concessão dos quiosques firmada a partir da Resolução 140 de 16 de dezembro de 1904 . Estes edificações deveriam obedecer a dois tipos de modelo: o primeiro de apenas um andar e segundo com dois andares - ambos deveriam ser de seção circular ou poligonal. Ver: O Município de Belém. Relatórios de Intendência de 1903, 1904 e 1906.

${ }^{31}$ Lei n. 461 de 6 de setembro de 1906. O Município de Belém. Relatório de Intendência Municipal. 1908. P. 143.

URBANA, V.5, no 7, out.2013 - Dossiê: Urbanistas e Urbanismo: a escrita da história... - CIEC/UNICAMP
} 
Por esse tempo, Antônio Lemos já havia se firmado como uma espécie de "todo poderoso" local ${ }^{32}$. Como já apontado, as concessões feitas a pessoas próximas a si foi uma característica marcante do seu governo ${ }^{33}$. Muitos engenheiros foram beneficiados neste processo. A oposição politica, personificada em Lauro Sodré, não deu trégua durante todo o governo de Antônio Lemos, denunciando e fazendo severas criticas ao modo como ele, conduzia a urbanização da cidade e utilizava o erário público. Estabeleceu-se então, um longo período de acusações mútuas por meio dos jornais locais, principalmente na Folha do Norte e n'A província do Pará.

No ano de 1907 a Folha do Norte denunciou em suas páginas, sob o pretexto de estar defendendo os comerciantes locais, a importação irregular de cimento, feita com a conivência da Intendência Municipal. A denúncia deste periódico ressaltava que:

A importação de cimento feita pela Intendência não tem por único fim utilizalo nas obras públicas que está emprehendendo, mas serve também para obras particulares.

É assim que conforme denúncia que recebemos, e mandamos pessoalmente verificar, esse cimento é empregado na construção de uma Villa Operária à travessa Dr. Moraes, onde há pouco tempo, existiam cerca de 400 barricas, com a seguinte marca IMB [Intendência Municipal de Belém] que revela claramente a sua origem.

É um dos menores escândalos da época e quem perde com eles são, em primeiro lugar o erário federal, porque esse cimento passa na alfândega livre de direitos, e em segundo, o comércio que vende o artigo e que é, por essa forma, prejudicado, porque é claro que não pode competir com a municipalidade. Também no Mercado Velho existiam várias barricas de cimento assignaladas pela mesma marca (Folha do Norte: O cimento que a

32 Lemos foi, de 1897 a 1911, presidente do Partido Republicano Paraense e Intendente Municipal de Belém. Durante quatorze anos não houve quem pudesse fazer frente ao seu poder, pois além de Coronel das forças armadas Nacional, Senador, presidente do Partido Republicano Paraense e Intendente, O PRP elegeu por longos anos a maioria, na Câmara de vereadores e de deputados. Quando Lemos desbancou o candidato de Lauro Sodré a governador, Justo Chermont, candidatura que havia sido acordada entre Lemos e Sodré desde 1898, elegendo Augusto Montenegro para governador em 1900, consolidou o seu poder no Estado do Pará. Lemos indicava todos os nomes e o governador acatava. Nada era feito sem o "aprovo" do Intendente. Este poder começou a enfraquecer-se com a eleição de João Coelho a governador, em 1909. Dentro do PRP havia muita insatisfação com o poder e os desmandos de Antônio Lemos, mas somente em 1910, a politica de favorecimentos adotada por Lemos, começou a ser contestada, dando inicio a uma crise politica neste partido e no estado do Pará. ver: (ROCQUE, 1996).

${ }^{33}$ Exemplo de concessão que provocou muitos protestos foi o contrato que Antônio Lemos, tentou por em vigor, entre a Intendência e o Sr. Salvador Ferreira Costa. Tratava-se de mais uma concessão, pelo período de 90 anos de uma vasta área da cidade, iniciando na travessa Piedade, indo até a Generalíssimo Deodoro, e do litoral até a av. São Jeronimo, abrangendo todo o bairro do Reduto e parte do Umarizal atualmente, parte central da cidade. O concessionário se comprometia realizar o dessecamento, saneamento e embelezamento de toda a área, constituída em grande parte por terras baixas, alagadiças e intransitáveis, a construir uma doca para abrigo de embarcações pequenas; edificar um mercado modelo; construir um parque; abrir novas ruas e avenidas, retificar e alargar as ruas existentes. Em troca o concessionário receberia os direitos de: desapropriar os terrenos da área, direito sobre todas as benfeitorias, isenção de todos os impostos municipais e estaduais por 90 anos, para a construção de edifícios mercados e mais serviços, cessão gratuita de todos os terrenos pertencentes a municipalidade existente na área, isenção dos direitos aduaneiros, para materiais importados e de impostos estaduais para exploração e execução de serviços executados, exploração das avenidas, ruas e parques que tivesse construído. As concessões Municipais. Folha do Norte. 8 agost. 1910.

URBANA, V.5, n 7, out.2013 - Dossiê: Urbanistas e Urbanismo: a escrita da história... - CIEC/UNICAMP 
Intendência importa. 18 jun. 1907; O escândalo do cimento, 20 jun. 1907; O cimento, 26 jul. 1907; O cimento 27 jul. 1907).

A 'Vila Operária', a qual a Folha do Norte referia-se na denuncia transcrita acima, era na verdade uma das obras arquitetônicas de Francisco Bolonha, a Vila Bolonha, e o 'Mercado Velho' é o atual Mercado Bolonha, que na época passava por uma reforma da qual ele era o concessionário. No dia seguinte a esta denúncia, Bolonha publicou uma nota defensiva na Província do Pará, dando a sua versão sobre o que estaria ocorrendo:

A Folha do norte, em seu numero de hoje, sob o título $O$ cimento que a intendência Importa, faz uma injusta acusação contra a Intendência Municipal, que, incidindo sobre aquela repartição, vem refletir com a mesma intensidade sobre meu nome, em que me apresso em defender [...]. A parte verdadeira da denuncia que recebeu a Folha do Norte é o facto de existirem, há bem pouco tempo, em depósito na obra da construção de prédios da minha propriedade, a travessa Doutor Moraes, perto de 400 barricas de cimento com a marca I.M.B. E a parte falsa da mesma denuncia é o fato de haverem sido essas barricas de cimento importadas pela intendência Municipal e haverem gozado da isenção de direitos, que a lei concede aos materiais importados para melhoramentos municipais, como passo a provar com dados irrefutáveis.

De meados do ano findo de 1906 até a presente data, tenho importado da Europa 2,500 barricas de cimento, destinado a execução de obras municipais a meu cargo, gozando, por conseguinte, dos favores de serem isentas de direitos de entrada, em virtude da lei federal em vigor, que regula a matéria.

Com o único fim de facilitar a Intendência Municipal o processo de requisição da isenção de direitos para esse material, no ministério da fazenda, faria e o faço ainda, virem todas as remessas consignadas a Intendência municipal, trazendo a marca I.M.B. Mas o valor correspondente a esses embarques era e é pago por mim, e bem assim as importâncias todas dos direitos aduaneiros.

$[\ldots]$

As faturas e demais documentos de embarque relativos a estas remessas, vieram todas em nome do Senador Antônio Lemos, intendente Municipal de Belém, e por ele foram assinados os respectivos despachos de importação ( 0 cimento que a Intendência Importa. A província do Pará. 19 de jul.de 1907).

Mesmo Francisco Bolonha tendo dito que pagava as taxas alfandegárias, o articulista da Folha do Norte reagiu com ironia a sua publicação, dando uma resposta para ridicularizá-lo diante da cidade:

Quem é que nega aqui às intendências isenção de direitos que a lei the concede? $O$ que se profilga é o abuso delas importarem, para negócio, materiais de construção, que de outro modo pagariam o despacho alfandegário.

O que fere de frente as expressões claras da lei é esse arranjo inqualificável que sr. Lemos e, que estão a praticar vários municípios, espoliando a nação 
e a fazenda à sombra do favor legal, uma concorrência desonesta ao comércio que vende o artigo.

Não nos admira que a Província defenda o escândalo como coisa legitima, e ela própria, de palacete, máquinas elétricas e typo novo, é já um escândalo que afronta a população, como escândalo também é o seu proprietário, de quem se pode dizer como se diz o vulgo:- Quem te viu quem te vê.

Defenda a "Província" o cimento e converta lá o seu amigo Bolonha em contratante de obras municipais. O pretexto não obumbra a verdade nem cohonesta o escândalo. Converta [o Bolonha] em cônsul. Converta lá no que quiser. A respeito deste caso ignóbil de cimento o juízo público está formado (O cimento. Folha do Norte. 26 de jul. 1907).

Ao denunciar irregularidades na administração de Antônio Lemos, o jornal laurista ${ }^{34}$,Folha do Norte, construía a sua oposição política, onde o argumento central era a ideia de que Antônio Lemos governava apenas para um ciclo restrito de pessoas composto por: seus amigos, seus parentes e seus correligionários políticos. Nas palavras mais precisas dos articulistas da Folha do Norte:

Acreditamos que a intendência de Belém não venda o cimento que importa, mas que o importa para servir a amigos ou consente que estes o façam em seu nome, é coisa que já não sofre dúvida, segundo as asseverações das denúncias que nos são enviadas a respeito e já agora do próprio autor do artigo estampado ontem nos "A pedido" da Província. Engenheiro Bolonha perde, portanto, o seu precioso tempo, exigindo por tantas indústrias rendosas, diligenciando defender-se das acusações que lhe cabem no caso (O Escândalo do Cimento. Folha do Norte. 20 de jul. 1907).

Como o poder de Antônio Lemos, também, apoiava-se nas alianças que fazia com os intendentes dos outros municípios do Pará, a Folha buscava mostrar que as benesses oferecidas por este Intendente, transpunham os limites da capital, indo garantir apoio para seu governo em outros espaços geográficos do Pará, envolvendo outros municípios na trama política e financeira que tinha como principal alicerce a modernização da cidade. Para atingir seu objetivo, o articulista laurista garantia, portanto, que "a intendência de Cametá não faz muito tempo que recebeu mil barricas daquele artigo e o vendia francamente a quem Ihe quisesse comprar. ${ }^{35 "}$ Além disso, expunha que:

Só pelo "Rio Negro", entrando a 24 do corrente da europa, vieram pra nossas praças 4.000 barricas de cimento destinadas aos seguintes recebedores:

A.M. Ferreira Sobrinho, 10; S Aguiar \& C. (intendência de Gurupá), 200; A.S. De Freitas \& C. 500, Salvador Marques \& C. 200; Pereira de Arcanjo \& C. 60; J. Gaston \& C. 100; Manoel Canceiro a costa, 250; governo do Estado, 1800; intendência de Breves, 200, total $=1000$ barricas.

\footnotetext{
${ }^{34}$ Alcunha pela qual ficaram conhecidos e assumiam-se os partidários de Lauro Sodré.

35 Idem.

URBANA, V.5, n 7, out.2013 - Dossiê: Urbanistas e Urbanismo: a escrita da história... - CIEC/UNICAMP
} 
Destas 200 não pagaram direitos alfandegários, e calculando-se os de cada uma em $\$ \$ 500$, temos que para os cofres da união deixaram de entrar, só nesta remessa, 7. $700 \$ 000$ (O cimento. Folha do Norte. 26 de jul. 1907).

Mas quando o assunto era denunciar os aliados de Antônio Lemos, por muito tempo, Francisco Bolonha foi o alvo preferido da Folha do Norte. Como a denúncia que dizia respeito à cobrança de impostos que, supostamente, Francisco Bolonha impunha a todos que comercializavam aves na cidade. Segundo este jornal, baseado na vigésima cláusula do contrato de concessão, assinado por ele com a Intendência, este engenheiro colocava cobradores em vários pontos da cidade a fim de arrecadar 120 réis por cada ave, viva ou morta, que era desembarcada em Belém, embora, a cláusula supracitada limitasse esta cobrança a aves que adentrassem no Mercado Municipal ${ }^{36}$. A vigésima cláusula do contrato em questão, a que a Folha do Norte referia-se estipulava o seguinte:

Fica pertencendo ao concessionário, engenheiro Francisco Bolonha, durante todo o prazo deste contrato, a importância do imposto de aves de quaisquer espécies, vivas ou mortas, entradas no Mercado Municipal, cuja cobrança será pelo mesmo concessionário efetuada (Contrato de Concessão. 30 de nov. 1906. ).

Alguns dias após denunciar a cobrança de impostos sobre aves fora do Mercado de Carne, a Folha anunciou o fim desta cobrança irregular, por meio da seguinte nota: "O sr. Intendente mandou suspender ontem a taxa abusiva cobrada sobre as aves desembarcadas no Littoral, e que se destinava as algibeiras do sr. Bolonha e do sr. Pindobussú Lemos. O homem está de uma generosidade que espanta ${ }^{37}$."

Antônio Lemos acabava por ceder a algumas pressões dos lauristas, mas apenas quando não havia margem para defesa. Assim como, a forma como Antônio Lemos e seus aliados políticos tomavam contam da cidade, "prolongando seus tentáculos" para além do que Ihes garantia o que estava determinado nos contratos firmados entre eles, fornecia aos lauristas uma rica fonte de argumentos contra a estada dele no cargo de Intendente de Belém. Neste caso, o articulista da Folha no Norte, aproveitando-se deste ato de Bolonha, procura demonstrar o abuso de poder presente nas atitudes dos aliados de Antônio Lemos:

[...] diz claramente o contrato - Imposto de aves, vivas ou mortas entradas no Mercado Municipal; entretanto, o sr. Bolonha, tomando por mercado toda a cidade de Belém, colloca seus agentes cobradores por todo o litoral e nas estações de Belém e em S. Braz, da E. F. de São Braz, e por esses postos nenhuma ave passa sem que o seu portador pingue 120 réis por cada uma

\footnotetext{
${ }^{36}$ Extorsões ao povo. Folha do Norte. 1 de jul. 1910.

37 ECHOS E NOTICIAS. Folha do Norte. 15 de jul. 1910.

URBANA, V.5, no 7, out.2013 - Dossiê: Urbanistas e Urbanismo: a escrita da história... - CIEC/UNICAMP
} 
(Extorsões ao povo. Folha do Norte. 1 de jul. 1910).

As denúncias de abuso de poder por parte da Intendência de Belém, veiculadas na Folha do Norte, quando tinham Francisco Bolonha como alvo principal, acabavam por envolver Pindobussú Lemos, filho de Antônio Lemos. No início de janeiro de 1911, aproveitando-se do fato de Pindobussú Lemos ter assumido publicamente, em um artigo publicado por ele no jornal a Província do Pará, que era sócio de Francisco Bolonha na concessão dos quiosques, a Folha do Norte publicou uma longa matéria no intuito de reforçar o batido argumento de que Antônio Lemos usava o seu cargo público apenas para favorecer aos seus. Referindo as declarações de Pindobussú Lemos na Província do Pará, o articulista da Folha do Norte, ressaltava o seguinte:

Das palavras do filho do sr. Antônio Lemos deprehendia-se muito bem a sua resolução de explorar esta valiosa qualidade, que lhe permitia compartilhar os benefícios pecuniários do monopólio de que o sr. Bolonha figurava como único concessionário (OS KIOSKES. Folha do Norte. 12 de jan. 1911.).

Não tendo contra Pindobussú Lemos argumentos que provassem haver ilegalidade quanto à sua participação em negócios que envolviam a Intendência, a Folha do Norte buscou na moral, ou na falta dela, apoio para construir argumentos que depusessem contra Antônio Lemos. Para isto, transcreveu literalmente, o trecho da matéria onde Pindobussú Lemos assume a sociedade com Francisco Bolonha:

Mal sabia o sr. Bolonha que lembrando-se de mim para este negócio (o dos Kioskes), cometia o mais horroroso de todos os crimes, pois é de lei que o filho do Intendente de Belém não pode absolutamente, associar-se a qualquer empresa, cuja a concessão seja dada pela comuna de seu progenitor e chefe (OS KIOSKES. Folha do Norte. 12 de jan. 1911.)

O articulista do jornal segue sua argumentação, apoiando-se no fato de que o filho do Intendente, mesmo acreditando que havia impeditivos legais para a sua associação ao negócio cedido a Francisco Bolonha, teria concretizado a sociedade, demonstrando sua imoralidade de caráter - imoral para os opositores de Antônio Lemos, era beneficiar os que Ihe apoiavam politicamente. Referindo-se ao trecho transcrito acima, a Folha do Norte posicionava-se da seguinte maneira:

Isto seria suficiente para provar o fundo móvel do caráter de quem subscreveu este período, achando moralidade e naturalidade na sua partilha dos privilégios, pois não consta de lei a proibição que veda ao filho do Intendente de gozar dos monopólios concedidos por seu pae. Mas não é nosso 
intuito analysar a defesa do sr. Pindobussú. A ninguém deixou de causar repugnância, no devido tempo, semelhante critério (OS KIOSKES. Folha do Norte. 12 de jan. 1911.).

Para desbancar Antônio Lemos do poder, a Folha do Norte buscava mostrar a que preço a cidade estava sendo modernizada e quem de fato, em sua perspectiva, eram os beneficiados com esta modernização. Mas apesar de todas as concessões, feitas a Bolonha e a diversos outros capitalistas e engenheiros que atuaram na modernização da cidade de Belém e do estado do Pará, terem sido cedidas sob a acusação da oposição de serem incentivo e apoio aos monopólios no âmbito municipal, a alegação da Intendência Municipal era de que não havia dinheiro suficiente para urbanizar a cidade e de ser esta a alternativa para dar prosseguimento ao plano urbanístico traçado para a capital do Pará. Nas palavras do Intendente Municipal:

Si concedestes vantagens os particulares que se encarregaram da execução destes custosos trabalhos de saneamento, e embelezamento, muito maiores vantagens colherão os munícipes e mesmo a Municipalidade, a cuja propriedade reverterão dentro de certo prazo, todos os melhoramentos perfeitamente conservados e sem indenização de espécie alguma, sem forma nem figura de juízo (OS KIOSKES. Folha do Norte. 12 de jan. 1911.).

Ressalte-se que Antônio Lemos não estava inventando uma nova forma de urbanizar a cidade. Concessões e contratos com particulares faziam parte do processo de administração das cidades brasileiras desde o período imperial e continuou fazendo-se presente no início do século XX. Trabalhos de outros pesquisadores relatam a presença desta prática em cidades como São Paulo e Rio de Janeiro (BECHIMOL, 1990; CHALHOUB, 1996; CERASOLI, 2004).

No ano de 1910, por conta da aproximação do ano eleitoral que seria em 1912, as denúncias e acusações acirraram-se. Os lauristas expressavam abertamente o temor de que Lemos se candidatasse e vencesse novamente, diziam eles:

[Antônio Lemos] transformou o governo dessa cidade em propriedade sua, fazendo-se já reeleger cinco vezes, com a maior ofensa a dignidade do regimen, que não permite perpetuidade no exercício das funções públicas e preparando-se para, em 1912, galgar mais um triênio, se até lá Deus se não amerceiar desta infeliz terra, enviando-Ihe a salvação no juízo dos homens ( $O$ município. Folha do Norte. Fev. 1911).

E foi a politica urbanística de Antônio Lemos, o argumento utilizado pelos seus opositores para conquistar o apoio de setores da população. O contrato dos quiosques foi um dos mais contestado pelos opositores políticos deste Intendente. Os articulistas URBANA, V.5, n 7, out.2013 - Dossiê: Urbanistas e Urbanismo: a escrita da história... - CIEC/UNICAMP 
da Folha do Norte publicavam constantemente artigos onde propalavam a ideia de que, estes quiosques eram nocivos para o comércio local, por estarem espalhados por um espaço amplo e central da cidade, por serem isentos de impostos, por terem permissão para funcionar durante a noite, aos finais de semana e feriados, direito que era vedado aos outros comerciantes. Estes argumentos eram usados para convencer o povo de que o Intendente Municipal abusava do seu poder para fatiar a cidade entre seus amigos e familiares, principalmente, depois que foi descoberto que o filho de Antônio Lemos, Pindobussú Lemos, era sócio de Francisco Bolonha nesta concessão, embora o seu nome não constasse no contrato.

Após longos meses de disputas nos jornais entre lauristas e lemistas, no dia 30 de dezembro de 1910 estourou uma revolta popular na cidade. Na tarde deste dia, diante das latas de lixo exposta nos estabelecimentos do comércio de Belém, revoltados com a obrigatoriedade imposta pela intendência de que, a população e os comerciantes deveriam comprar as tais caixas sanitárias para acomodar o seu lixo, iniciou-se um 'quebra-quebra' na travessa 7 de setembro, alastrando-se por várias ruas do comércio da cidade. Neste dia com a chegada da policia e da cavalaria, mesmo havendo brigas e prisões, pode-se restabelecer a ordem na cidade. No dia seguinte, a empresa concessionária das latas de lixo divulgou nota nos jornais locais, falando da necessidade de se implantar o produto, visto que ele colaboraria com a higiene na cidade. Esclarecia que, em seu entendimento, o valor a ser cobrado era uma quantia módica $^{38}$. Porque se convenceram temporariamente ou porque as caixas sanitárias foram retiradas do comércio, no dia 31 de dezembro pela manhã, não houve tumultuo na cidade, mesmo assim a cavalaria se manteve na rua ${ }^{39}$.

Ainda no dia 1 de janeiro de 1911, teria circulado na cidade boletins convocando o povo para uma reunião na Praça da República. Houve conflito entre um jornalista d'A província do Pará e os "subversivos", o tumultuo juntou mais gente em frente ao "Café da Paz" e aos gritos os revoltosos desceram em direção ao jornal Folha do Norte - a cavalaria foi atrás. Houve discursos exaltados em frente a este jornal. Como no dia anterior, "apenas algumas prisões foram efetuadas, nada fora da normalidade 40 ".

O ano de 1911 chegou trazendo ventos de mudança para o Pará. No dia 2 de janeiro, explodiu em frente ao mercado de ferro uma revolta de peixeiros portugueses que quebraram os tabuleiros da concessão da Empresa Americana de veículos, por

\footnotetext{
${ }^{38}$ Nos 14. 257 prédios existentes no perímetro urbano, 6.426 pagariam 600 réis, 1.104 pagariam 750 reis e os restantes, em numero menor, pagariam entre 900 a 1 conto e 1800 reis. A província do Pará. 31 de dez. 1911.

${ }^{39}$ A Revolta. O Estado do Pará. 1 de jan. 1911.

${ }^{40}$ Idem.

URBANA, V.5, no 7, out.2013 - Dossiê: Urbanistas e Urbanismo: a escrita da história... - CIEC/UNICAMP
} 
serem obrigados a adquiri-los se quisessem vender o pescado fresco. Logo este ato virou tumultuo e um grupo saiu quebrando todos os tabuleiros e carros que encontravam pelo caminho. O 'quebra-quebra' gerou mais prisões e protestos. Na Rua 15 de novembro, um dos populares preso foi retirado da mão da policia pelos revoltosos. O movimento tomou grandes proporções, fecharam-se estabelecimentos comerciais, os protestos espalharam-se para os bairros de São Braz, Batista Campos e cidade velha. Logo os revoltosos começaram a incendiar carros e a tarde teria circulado um boletim convocando as classes trabalhadoras para a greve ${ }^{41}$.

Um grupo de pessoas destruiu um quiosque que ficava localizado na Castilho França (Boulevard da República), esquina com a Rua 15 de agosto (Presidente Vargas). Este ataque desencadeou uma série de outros assaltos aos quiosques da concessão Bolonha e a noite eles foram incendiados. No dia 3 de janeiro deu-se continuação aos protestos, com tentativa de incêndio ao mercado de ferro do Ver-oPeso. Houve troca de tiros entre os manifestantes e a policia. Na tarde deste dia, o então chefe de policia Vicente Epaminondas Pires Reis, fez circular na cidade um boletim, advertindo que "as pessoas bem intencionadas não tomassem parte nos agrupamentos e manifestações intempestivas no atual momento, sob pena da policia não se responsabilizar pelo mal que, porventura, Ihes venha suceder ${ }^{42 " .}$

Os saldos desta sublevação foram vários feridos, 60 quiosques incendiados e a renuncia de Antônio Lemos, cerca de cinco meses após o ocorrido ${ }^{43}$. Com o seu poder estremecido, o "homem de ferro" da cidade de Belém, após ter sido desafiado por seus inimigos políticos e por populares, sob a alegação de que o Partido Republicano Paraense corria o risco de cingir sob o seu comando (ROCQUE, op.cit., p. 313), dado os últimos acontecimentos, adotou a estratégia de renunciar, para mais tarde retornar ao cenário politico. Depois de tantos anos governando a cidade com mão forte, Antônio Lemos partiu para Europa, mas deixou atrás de si sua sombra onipotente - o jornal A Província do Pará44. Durante todo o restante do ano de 1911 e parte de 1912, seguiram-se acusações entre lauristas e lemistas ${ }^{45}$ nos jornais locais - os primeiros representados pela Folha do Norte e os últimos pelo já citado A província do Pará.

De Portugal, Lemos seguiu para o Rio de Janeiro, retornando a Belém em fevereiro de 1912, visando atuar em prol dos candidatos do seu partido, nas eleições

\footnotetext{
${ }^{41}$ Repulsa a uma afronta. O Jornal. 3 de jan. 1911.

42 O Estado do Pará. 4 de jan. 1911.

43 No dia 12 de jun. 1911, Antônio Lemos oficializou a renuncia que já vinha anunciando há tempos, porém, não havia merecido credibilidade de seus opositores que não apostaram que ele se afastaria do poder logo no primeiro conflito. Folha do Norte. 13 jun. 1911.

${ }^{44}$ Partir? Folha do Norte. 13 de jul. 1911; Convite. A Província do Pará. 12 de jul. de 1911.

45 Termos pelos quais ficaram conhecidos os partidários de Antônio Lemos e de Lauro Sodré que participaram das agitações politicas ocorridas no inicio do século XX no Estado do Pará.

URBANA, V.5, no 7, out.2013 - Dossiê: Urbanistas e Urbanismo: a escrita da história... - CIEC/UNICAMP
} 
de junho do mesmo ano. Nestas eleições seriam escolhidos o novo Intendente, o Conselho Municipal, um terço do Senado Estadual e a câmara dos deputados ${ }^{46}$. Com o retorno de Antônio Lemos a cidade, seus adversários políticos, temendo vê-lo recolocado no poder, fundaram o Centro de Resistência ao lemismo ${ }^{47}$.

A campanha eleitoral, como já se esperava, seguiu tumultuada na cidade regada a acusações mútuas. No dia 23 de junho, após a apuração simples, instaurouse uma "verdadeira Torre de Babel". O Estado do Pará anunciava que o candidato do PRP, apoiado por ele, havia vencido - garantindo que foram eleitos todos os seus candidatos e que o Partido Federal elegera um terço dos seus. A Folha do Norte garantia que os seus candidatos - do Partido Republicano Federal - haviam sido todos eleitos e o PRP elegera um terço. Do mesmo modo A Província do Pará propalava "Vencemos!!!" - garantindo que todos os seus candidatos haviam sido eleitos ${ }^{48}$. Contudo, na apuração oficial dos votos os vogais (vereadores) lemistas foram impedidos de entrar no palácio municipal, onde estavam ocorrendo às apurações, houve tumultuo e troca de tiros entre estes e os que se encontravam no interior do palácio. Como consequência, ocorreu à duplicata da junta apuradora, no fim saíram dois resultados eleitorais: a junta presidida pelo candidato do PRP, Virgílio Mendonça, declarou ter sido ele o Intendente eleito, além de, três vogais do Federal e três do Republicano. A junta do Conservador declarou ter sido eleito o candidato deste partido, Pedro Chermont de Miranda e para vogais quatro dos seus candidatos e dois do PRP (Rocque. op.cit. p. 363).

Diante deste quadro caótico houve ameaça de intervenção federal. Lauro Sodré que estava na capital do país, desembarcou em Belém no dia 25 de agosto, mandado para intermediar as negociações, mas sua presença teve o efeito de gasolina para um incêndio. No dia 28, três dias após a sua chegada, Sodré sofreu um suposto atentado a sua vida, anunciado anteriormente na imprensa local ${ }^{49}$. No dia seguinte, a cidade amanheceu, mais uma vez sitiada. No suposto atentado, um popular fora assassinado.

\footnotetext{
${ }^{46}$ Concorreram ao cargo de Intendente Municipal: Pelo PRP - antigo partido de Antônio Lemos - Virgilio Mendonça, pelo Partido Conservador Republicano - partido originado da cisão do PRP após a queda de Antônio Lemos e fundado pelo seu genro e sobrinho Arthur Lemos - Pedro Chermont de Miranda e pelo Partido Republicano Federal Antônio Martins Pinheiro.

47 No processo de pedido de indenização aberto por Lemos contra o estado do Pará, está relatado que vários centros com este fim foram fundados na cidade em 1912. Processo Antônio Lemos. Centro de Memória da Amazônia. Cartório Odon. 1917.

48 Ver: Vencemos! A província do Pará. 23 jun. 1912. A vitória do Partido Republicano Paraense e a derrota da dissidência. Estado do Pará. 23 jun. 1912. Folha do Norte. 23 jun. 1912.

49 No dia 22 A Província do Pará publicara uma denuncia de que havia um plano tramado pelos lauristas para simular um atentado a Lauro Sodré no dia da sua chegada, para incriminar os lemistas. No mesmo dia "A Capital" - jornal a serviço do PRP - garantia que a nota d'A Província, era uma armação, pois tentariam o feito e colocariam a culpa no candidato deste partido - Virgílio Mendonça.

URBANA, V.5, n० 7, out.2013 - Dossiê: Urbanistas e Urbanismo: a escrita da história... - CIEC/UNICAMP
} 
Naquele dia 28 de agosto, circularam na cidade boatos aterradores, perturbando a ordem publica, uma multidão juntou-se nas imediações do necrotério municipal, onde se encontrava exposto o cadáver do popular, havendo certo número de indivíduos armados em atitude ameaçadora contra os seus adversários políticos, a quem atribuíam a autoria do atentado a vida do Senador Lauro Sodré. Pesou sobre a cidade uma atmosfera de apreensão - determinando o fechamento do comércio durante todo aquele dia. No dia seguinte, continuou a agitação na cidade, "sem que as autoridades policiais provessem o desarmamento dos indivíduos". Após uma reunião que se realizara na Praça da República, em frente ao Hotel "Café da Paz", na tarde daquele dia, no qual foram pronunciados discursos veementes, em que se pregava o extermínio dos lemistas, a multidão promoveu um assalto à mão armada ao edifício, onde então funcionava a redação, administração e oficinas de impressão do jornal A Província do Pará, situado naquela praça. Segundo a narrativa de Antônio Lemos, entrincheiraram-se os amotinados em diferentes pontos da praça, de onde dirigiam continuo foco de fuzilaria, tendo-se juntado aos atacantes, que se achavam armados de rifles e carabinas, outros grupos, também armados, vindos dos arredores da cidade, organizados em batalhões e brigadas - ditas de defesa. A fúria do ataque teria se prolongando por mais de cinco horas, espalhando pânico na cidade e paralisando o transito de bondes e de outros veículos pelo resto da noite. Os assaltantes do referido prédio, atearam fogo nele, inflamando-o com querosene, sendo no meio da noite a cidade iluminada pelo clarão do incêndio. Em seguida, depois de destruído pelo incêndio o prédio à Praça da Republica, dirigiram os assaltantes, outro ataque a residência da família do coronel Antônio Lemos, onde este se encontrava em companhia da sua esposa - como declarou posteriormente Antônio Lemos: "crendo na inviolabilidade do lar que a constituição federal the garantia." Os amotinados investiram contra a casa do agora Coronel Antônio Lemos, precedendo um ataque de fuzilaria cerrada por algumas horas, depois do que a saquearam, retirando uma imensa coleção de objetos de arte, mobiliário, joias, pedras preciosas e incontável número de outras coisas de valor. Depois do saque e da depredação, os assaltantes, também incendiaram este prédio, reduzindo-o a ruinas. Para fugir a sanha dos amotinados, Antônio Lemos e sua família, no decorrer do ataque a fuzilaria que precedeu o saque, refugiaram-se em uma casa vizinha, onde passou a noite. Sobrou-Ihes, naquele momento, a roupa caseira que traziam na hora do saque. Os assaltantes, na manhã seguinte - dia 30 de agosto - descobrindo Lemos abrigado na 
casa que the servira de refúgio, em meio a insultos, levaram-no como prisioneiro a casa do Intendente Municipal ${ }^{50}$.

De todo o exposto, é importante observarmos que, não interessa julgarmos o modo de fazer politica destes homens, pois não é função do historiador, nem deve ser seu objetivo, empregar juízo de valor sobre a ação dos homens que atuaram na construção dos processos históricos, visto que suas atitudes já estão à mercê das constantes revisões da escrita da História (RICCOEUR, 2007, p.335). Compreender as ações dos articulistas da Folha do Norte como parte da disputa politica estabelecida no estado do Pará durante a primeira República é mais importante do que definir a veracidade das acusações de abuso de poder contra o Intendente Municipal. Antônio Lemos estava no poder a quase 14 anos, sendo eleito e reeleito por várias vezes consecutivas e caminhava para mais um, provável, mandato, já que não havia limitação do número de vezes que um politico poderia ocupar o cargo de Intendente Municipal e Lemos não sofria derrota nas eleições desde que assumiu este cargo, em 1897. Durante grande parte desse tempo, estabeleceu parceria política com Augusto Montenegro, eleito governador do estado em 1901. Mesmo a Constituição do Estado do Pará não permitindo a reeleição do governador, Antônio Lemos convocou um Congresso do Partido Republicano objetivando propor uma emenda que alterasse esta determinação. A emenda foi posteriormente submetida e aprovada no Congresso Legislativo. Augusto Montenegro recandidatou-se em 1905 e venceu as eleições (SARGES. op.cit. p. 63-65).

Sobre este processo de modernização e disputas politicas ocorrido em Belém do Pará, pelo menos, três análises podem ser feitas. A primeira assenta-se sobre a politica de concessão adotada por Antônio Lemos - que entendo, estava assentada na politica da dádiva e da retribuição (BOURDIEU, 2011, p. 157-179) ${ }^{51}$. Sendo uma politica de reciprocidade, a dádiva remete a retribuição. Exemplo disto, era o ritual que se estabelecia na cidade no dia 17 dezembro, durante a "era Lemos". Todos que

\footnotetext{
50 Dados retirados do processo que Antônio Lemos e sua família moveu contra o Estado do Pará do ano de 1913 a 1936, pleiteando indenização por danos morais e ressarcimento dos valores perdidos no assalto ao prédio d'A Província do Pará e a sua residência. Este processo correu por anos, chegando ao Supremo Tribunal Federal. Antônio Lemos faleceu em 1913 no Rio de Janeiro, para onde rumou após o ocorrido. Sua esposa D. Ignez Maria de Lemos deu prosseguimento ao processo, morrendo em 1931, sem vê-lo chegar ao final. Seus herdeiros prosseguiram processando o Estado. Em 1936 o STF deu ganho de causa aos herdeiros de Antônio Lemos. Porém, sem direito a indenização por danos morais e sendo, condenados a dividir os custos do processo com o réu - o Estado do Pará. Mesmo este processo tendo vindo a público, somente no ano de 2011, esta narrativa foi por diversas vezes ratificada na literatura local e nos relatos de memória dos que viveram o episódio. Processo Antônio Lemos. Centro de Memória da Amazônia. Cartório Odon. 1917. P. 12 -14.

51 Originalmente, a teoria da dádiva foi sistematizada por Marcell Mauss num ensaio clássico intitulado "Ensaio sobre a dádiva: forma e razão da troca nas sociedades arcaicas", publicado inicialmente no ano de 1924, e que se encontra reproduzido numa coletânea organizada por Georges Gurvitch intitulada Sociologia e antropologia (MAUSS, 2003).
}

URBANA, V.5, n० 7, out.2013 - Dossiê: Urbanistas e Urbanismo: a escrita da história... - CIEC/UNICAMP 
estavam ou queriam estar sob duas dádivas, sabiam que tinham obrigação de reverencia-lo em seu natalício. Desde as cinco horas da manhã, sua casa era visitada pelos que firmavam com ele o pacto de reciprocidade politica ou econômica. Banquetes eram oferecidos e, invariavelmente, noticiava-se em seu jornal, $A$ província do Pará, a lista de pessoas que o visitaram, assim como, os presentes mais relevantes oferecidos a ele ${ }^{52}$. Lemos, ao conceder "favores" aos seus, deixava implícito que seu ato os obrigava a uma retribuição. Urbanizando a cidade por meio da dádiva de monopólios a médicos, engenheiros, advogados e capitalistas em geral, o Intendente Municipal, mais que criava uma politica de cessão de monopólios, garantia para si, aliados políticos que o mantiveram no poder por 14 anos. Contudo, este pacto foi quebrado pelos que não se sentiam suficientemente incluídos nos favorecimentos de Antônio Lemos ou que passaram a cobiçar o lugar ocupado por ele. Este raciocínio nos leva a segunda análise deste processo.

Ao estabelecer-se a disputa politica pelo poder local, os periódicos que circulavam em Belém, foram utilizados pelos políticos e articulistas desses jornais, como campo de força, definido por Bourdieu (1989) como espaços que legitimam disputas entre indivíduos que compartilham interesses, valores e códigos. Contudo, eles, visando o poder de fato, ultrapassaram os limites do convencimento e da violência verbal, ambos presentes nas publicações diárias destes periódicos. Ao apoiarem a adoção da violência física, transcenderam a busca pelo fazer crer, que se processa por meio dos embates de ideias, resultando em aumento de capital simbólico (BOURDIEU, 1989). Vivendo em um período politico repleto de incertezas, regido por oligarquias locais, em um momento em que a capacidade de fazer crer, estava à mercê dos constantes tumultos políticos da primeira República - ao perceberem que não conseguiriam ganhar a batalha com o embate de palavras, optaram pelo incentivo ao uso da força, para eliminar seus adversários (BOURDIEU, 1989, p.14-15).

Outra análise possível repousa no modo de fazer politica na dita República Velha. A agitação comumente espalhava-se pelos estados e não era bem vista pelo governo central que buscou soluciona-las adotando a politica dos governadores. Para consolidar o regime republicano, julgou-se necessário alijar o povo do processo eleitoral democrático. Era dos Estados que se deveria governar na República, sobre as multidões que contestavam nas ruas (CARVALHO, 2003, p. 98). No momento das agitações politicas, das quais Belém foi palco em 1911 e 1912, a população encontrou um momento propicio para manifestar sua insatisfação pelo tipo de politica que a

\footnotetext{
52 Este ritual foi citado no processo de pedido de indenização que Lemos moveu contra o estado do Pará, após os incêndios de suas propriedades. op.cit.

URBANA, V.5, n 7, out.2013 - Dossiê: Urbanistas e Urbanismo: a escrita da história... - CIEC/UNICAMP
} 
República reservava para ela. As imposições de um modo de viver considerado civilizado se chocavam com os hábitos culturais e o poder aquisitivo desta população. De repente, antigos hábitos cotidianos passaram a ser contestados e vistos como um perigo para a vida nas cidades. Para normatizar o espaço citadino, colocou-se em vigor, de forma autoritária, exigências de salubridade e higiene que se contrapunham a estes hábitos. O baixo poder aquisitivo de peixeiros, carroceiros, leiteiros e diversas outras classes subalternas, que eram compelidas a adquirir compulsoriamente produtos para poder exercer seu oficio, levou-as a partilhar com a elite politica belenense de uma causa, aproveitando-se de mais um momento de instabilidade politica, advogaram por si, usando a força, quando não Ihes era permitido usar o voto.

\section{FONTES}

Jornais

A província do Pará.

Folha do Norte

O Estado do Pará

O Jornal

Relatório de Governadores e de Intendência

Código de Polícia Municipal. Lex: Leis e Resoluções Municipaes e Actos do Executivo, Belém, 1900.

Governador José Paes de Carvalho. Mensagem ao Congresso do Estado do Pará. Belém: Tip. do Diário Oficial. 1898.

Intendência Municipal de Belém. Cópias de contratos. Pará: typ. Pinto Barbosa e Cia. 1900.

Lauro Sodré. Mensagem para o Congresso do Estado do Pará. Belém: Typ. Do Diário Oficial, 1896.

O Município de Belém. Relatório de Intendência Municipal - 1892-1902

O Município de Belém. Relatório de Intendência Municipal - 1903

O Município de Belém. Relatórios de Intendência - 1904

O Município de Belém. Relatórios de Intendência - 1906.

O Município de Belém. Relatórios de Intendência - 1907.

O Município de Belém. Relatórios de Intendência - 1908.

Processo Antônio Lemos. Centro de Memória da Amazônia. Cartório Odon. 1917.

Relatório de Domingos José da Cunha Junior, presidente da província. Pará, Typ. do Diario do Gram-Pará, 1873.

Relatório Antônio Coelho de Sá e Albuquerque. Typ. Commercial de A.J. Rabello Guimarães. 12 de maio de 1860.

Revista da Semana. 1908. n/p.

Bibliografia

BASSALO, Celia Coelho (2008). Art Nouveau em Belém. Brasilia, DF: IPHAN/Programa Monumenta.

BOURDIEU (1989). O Poder Simbólico. Rio de Janeiro: Bertrand Brasil. URBANA, V.5, no 7, out.2013 - Dossiê: Urbanistas e Urbanismo: a escrita da história... - CIEC/UNICAMP 
BOURDIEU, Pierre (2001). Razões práticas: sobre a teoria da ação. Campinas, SP, Papirus.

BRESCIANI, Maria Stella(1985). Metrópoles, as faces do monstro urbano: As cidades no século XIX. Revista Brasileira de História. São Paulo: Marco Zero. CALABI, Donatella (2001). O papel de Paris na urbanística Italiana do século XIX: o mito da modernização. In: SALGUEIRO, Heliana Angotti (org). Cidades Capitais do Século XIX - racionalismo, cosmopolitismo e transferência de modelos. São Paulo, EDUSP.

CARVALHO, José Murilo (2003). Os três povos da República. Revista USP, n. 59. Set/nov.

CHALHOUB, Sidney (1996). Cidade febril: cortiços e epidemias na corte imperial. São Paulo: Companhia das letras

CERASOLI, Josianne (1998). A Grande Cruzada: os engenheiros e as engenharias de poder na Primeira República. Dissertação defendida no Programa de Pós-graduação em História da UNICAMP.

CERASOLI, Josianne (2004). Cidadania, Cidades e vilas - Historia , Obras publicas , Urbanização - Historia, Modernização, Leis - Brasil , Espaço (Arquitetura) - Aspectos sociais. Tese defendida no Programa de Pós-graduação em História da UNICAMP.

COELHO, Geraldo Mártires (2002). No Coração do Povo: O monumento à Republica em Belém - 1891-1897. Belém: Paka-tatu.

CORBIN, Alain (1989). O território do vazio: a praia e o imaginário ocidental.

São Paulo, Companhia das Letras.

DERENJI, Jussara (1998). Arquitetura Nortista: a presença italiana no início do século XX. Manaus: SEC.

HAROUEL, Jean-Louis (1994). Historia do Urbanismo. Campinas, SP: Papirus, 1990. ORTIZ, Renato. Mundialização da Cultura.

MENEZES, Ulpiano T. Bezerra de (2001). Prefácio: Cidade Capital, Hoje? In: SAlgueIRO, Heliana Angotti (org). Cidades Capitais do Século XIX racionalismo, cosmopolitismo e transferência de modelos. São Paulo, EDUSP.

RICCOEUR, Paul (2007). A memória, a História e o esquecimento. Campinas, SP: Ed. UNICAMP.

ROCQUE, Carlos (1973). Antônio Lemos e sua época. Belém: Amazônia Ed.

Culturais.

ROCQUE, Carlos (1996). Antônio Lemos e sua época: História politica no Pará. Belém: CEJUP.

URBANA, V.5, no 7, out.2013 - Dossiê: Urbanistas e Urbanismo: a escrita da história... - CIEC/UNICAMP 
SANTOS, Roberto (1980). História Econômica da Amazônia (1800-1920). São Paulo. T. A. Queiroz.

SARGES, Maria de Nazaré (2002). Belém: riquezas produzindo a Belle-Époque (1870-1912). Belém, Paka-tatu.

SEGAWA, HUGO (1981). Arquiteturas no Brasil - 1900-1990. São Paulo: UNESP, 1999.

SODRÉ, Lauro. Mensagem dirigida ao Congresso do Estado do Pará. Belém: Typ. do Diário Oficial.

WEINSTEIN, Barbara (1993). A borracha na Amazônia: expansão e decadência (1850-1920). São Paulo: Edusp. 